\title{
Profil Kemampuan Mahasiswa Tadris Matematika dalam Memecahkan Masalah Program Linear Ditinjau dari Perbedaan Tingkat Kemampuan Prasyarat dan Gaya Kognitif Fiel Dependent
}

\author{
Sitti Zuhaerah Thalhah \\ Program Studi Tadris Matematika, Institut Agama Islam Negeri (IAIN) Palopo \\ Jl. Agatis, Kel. Balandai, Kota Palopo, Sulawesi Selatan, Indonesia \\ E-mail: ztuhera@yahoo.com
}

\section{Article History:}

Received: $\mathrm{xx}-\mathrm{xx}-\mathrm{xxxx}$; Received in revised form: $\mathrm{xx}-\mathrm{xx}-\mathrm{xxxx}$; Accepted: $\mathrm{xx}-\mathrm{xx}-\mathrm{xxxx}$;

Available online: $\mathrm{xx}-\mathrm{xx}-\mathrm{xxxx}$

\begin{abstract}
This research has been carried out on Semester II students of Mathematics education Department, Faculty of Tarbiyah and Teacher Training at IAIN Palopo in 2017. The type of this research is qualitative descriptive. This research aims to describe the ability of students in solving Linear Program problems in terms of differences in the level of prerequisite ability and cognitive style. The instruments were (1) GEFT test, (2) Linear Algebra prerequisite ability tests, (3) Linear Program problem solving tests, (4) and unstructured task-based interviews. The results of this study are (1) research subjects with high prerequisite ability dependent field cognitive style, showing good ability in understanding problems correctly, planning solutions, solving problems in accordance with the plan and re-examining the results obtained. Subjects can solve Linear Program problems with graph and simplex methods (2) research subjects with prerequisite abilities while field dependent cognitive style, able to understand problems correctly, still unsure when carrying out solutions, but according to plan. Subjects can solve Linear Program problems with graphical methods and simplex methods, (3) research subjects with low prerequisite ability in field dependent cognitive style, lack of ability to understand problems, unable to carry out problem solving correctly, and unsure in explaining the completion steps taken.
\end{abstract}

Keywords: Solving Problems; Linear Program; Field dependent Cognitive Style; Prerequisite Ability.

Abstrak

Penelitian ini dilaksanakan di IAIN Palopo Fakultas Tarbiyah dan Ilmu Pendidikan Tadris Matematika Semester III Tahun 2017. Jenis penelitian ini adalah deskriptif kualitatif. Yang bertujuan mendeskripsikan kemampuan mahasiswa dalam memecahkan masalah Program Linier ditinjau dari perbedaan tingkat kemampuan prasyarat dan gaya kognitif. Instrumen yang digunakan adalah (1) tes GEFT, (2) tes kemampuan prasyarat Aljabar Linier, (3) tes pemecahan masalah Program Linier, (4) dan wawancara berbasis tugas tidak terstruktur. Hasil penelitian ini adalah (1) subjek penelitian dengan kemampuan prasyarat tinggi gaya kognitif field dependen, menunjukkan kemampuan yang baik dalam memahami masalah dengan tepat, merencanakan pemecahan, menyelesaikan masalah sesuai dengan rencana dan memeriksa kembali hasil yang diperoleh. Subjek dapat menyelesaikan masalah Program Linier dengan metode grafik dan simpleks (2) subjek penelitian dengan kemampuan prasyarat sedang gaya kognitif field dependent, dapat memahami masalah dengan tepat, masih kurang yakin saat melaksanakan pemecahan, namun sesuai dengan rencana. Subjek 
dapat menyelesaikan masalah Program Linier dengan metode grafik dan metode simpleks, (3) subjek penelitian dengan kemampuan prasyarat rendah gaya kognitif field dependent, kurang mampu memahami permasalahan, tidak mampu melaksanakan pemecahan masalah dengan benar, dan tidak yakin dalam menjelaskan langkah-langkah penyelesaian yang ditempuh.

Kata Kunci: Pemecahan Masalah; Program Linear; Gaya Kognitif Fiel Dependen; Kemampuan Prasyarat.

CProdi Tadris Matematika FTIK IAIN Palopo. This is an open access article under the Creative Commons - Attribution-ShareAlike 4.0 International license (CC BY-SA 4.0)

\section{Pendahuluan}

Matematika merupakan salah satu matapelajaran yang diajarkan pada setiap jenis dan jenjang pendidikan, baik pendidikan umum maupun pendidikan kejuruan, mulai dari pendidikan dasar sampai perguruan tinggi. Salah satu dasar pertimbangannya adalah karena matematika berperan sebagai sarana penataan nalar mahasiswa, yang berarti bahwa dalam matematika terdapat proses penggunaan aturan-aturan, membuat hubungan, memberi alasan, mengkomunikasikan ide matematika, memeriksa kebenaran hasil atau jawaban matematika yang diperoleh. Dengan mempelajari matematika, mahasiswa diharapkan dapat berpikir secara logis, analitis, kritis, dan kreatif serta diharapkan mampu memecahkan segala masalah yang dihadapi, baik masalah yang berkaitan dengan pelajaran matematika, maupun yang berkaitan dengan kehidupan sehari-hari.

Matematika memiliki objek kajian yang bersifat abstrak. Objek tersebut berupa fakta, konsep, prinsip dan operasi. Penyajian materi-materi pembelajaran matematika pada umumnya tersusun secara hirarkis, mulai dari yang paling sederhana hingga yang paling kompleks, materi yang satu merupakan materi prasyarat untuk materi berikutnya. Seorang mahasiswa tidak dapat mempelajari suatu materi tertentu apabila materi-materi prasyarat belum dikuasai. Oleh karena itu, cara mempelajari matematika berbeda dengan cara mempelajari mata pelajaran lainnya. Belajar matematika memerlukan kesiapan intelektual yang memadai, aktivitas mental yang tinggi dan kemampuan kognitif yang kompleks, seperti 


\section{Profil Kemampuan Mahasiswa Tadris Matematika...}

kemampuan berpikir divergen, kemampuan berpikir konvergen, kreativitas, persepsi, kemampuan pemecahan masalah, dan gaya kognitif 1 .

Mata kuliah Program linear merupakan salah satu mata kuliah wajib pada semester III Tadris Matematika. Sebagai mata kuliah wajib, tentunya para mahasiswa diharapkan dapat menguasai konsep-konsep Program linier, serta diharapkan dapat menerapkannya dalam kehidupan sehari-hari.

Berdasarkan pengalaman penulis selama mengajar, mata kuliah Aljabar linier, mahasiswa mengalami kesulitan melakukan penyelesaian masalah dengan metode eliminasi Gauss begitupun juga dengan mata kuliah Program linier mahasiswa kesulitan dalam melakukan penyelesaian masalah dengan metode simpleks. Hal ini disebabkan karena mahasiswa masih kurang mampu melakukan opersi pecahan dan bilangan bulat. Kesulitan (penyebab kesalahan) mahasiswa dalam menyelesaikan soal Program linier adalah: (1) kesulitan yang berkaitan dengan kemampuan pemahaman verbal, yaitu kurang mampu memahami makna kalimat; kurang mampu memahami hubungan antara objek dengan operasi hitung yang terkandung dalam pernyataan soal, (2) kesulitan yang berkaitan dengan kemampuan memanipulasi model matematika, yaitu kurang mampu memahami proses penyelesaian suatu persamaan linear dengan grafik; kurang memahami sifatsifat operasi hitung dan aljabart, dan (3) kesulitan dalam menafsirkan jawab model matematika menjadi jawab soal.

Hal ini terungkap dari penelitian Budiarto 20 mahasiswa Pendidikan Matematika IKIP Surabaya Angkatan 2013/2014 tentang penyelesaian soal program linear (berbentuk soal cerita), sebagai berikut: (1) $20 \%$ mahasiswa tidak tahu apa yang diketahui dari permasalahan, tetapi mengerti apa yang dicari dari permasalahan itu, (2) 50\% mahasiswa sudah memahami apa yang diketahui dan apa yang ditanyakan dari permasalahan, tetapi tidak mampu menulis model matematikanya, (3) 30\% mahasiswa dapat menentukan apa yang diketahui, apa yang ditanyakan dan mampu menulis model matematika

1 Erman Suherman, Strategi Pembelajaran Matematika Kontemporer (Bandung: Universitas Pendidikan Indonesia, 2001).

Al-Khwarizmi - 31 
serta dapat memilih konsep, prinsip dan rumus untuk menyelesaikan model matematika tersebut. Namun tidak satupun yang menjawab masalah yang dikemukakan. Jawaban mahasiswa terbatas pada jawab model matematika ${ }^{2}$.

Akramunnisa mengungkapkan dalam penelitiannya di kelas VIII SMPN 13 Makassar bahwa siswa dengan gaya belajara Fiel Dependen berpikir mencoba-coba dalam menyelesaikan soal yang diberikan dan berpikir menyeluruh namun karena tingkat kemampuan awalnya sehingga siswa dengan kemampuan awal tinggi yang dapat menyelesaikan masalah sedangkan kemampuan awal rendah sama sekali tidak dapat menyelesaikan masalah yang diberikan ${ }^{3}$.

Selain itu Baiduri dalam penelitiannya menyatakan bahwa tidak ada perbedaan yang signifikan hasil belajar matematika siswa SMP Muhammadiyah 1 Malang berdasarkan gaya belajar fiel dependen, fiel mixed, dan fiel independen, serta dinyatakan pula bahwa sebagian besar siswa bergaya belajar fiel mixed ${ }^{4}$.

Kemampuan tingkat kecakapan memecahkan masalah antara mahasiswa yang satu dengan yang lain berbeda. Sama halnya dengan taraf kecerdasan, atau kemampuan berpikir kreatif mahasiswa juga dapat berbeda dalam cara memperoleh, menyimpan serta menerapkan pengetahuan. Mahasiswa dapat berbeda dalam tingkat kemampuan prasyarat, cara pendekatan terhadap situasi belajar, bagaimana cara menerima, mengorganisasi, menghubungkan pengalaman-pengalaman mereka, dalam cara mereka merespons terhadap metode pengajaran yang mereka alami. Ada yang cepat, sedang, dan ada pula yang sangat lambat. Oleh karena itu,

2 Baharullah, "Kesulitan Siswa kelas I SMU YP. PGRI 3 Makassar Dalam Menyelesaikan Soal Terapan Sistem Persamaan Linear Dua Variabel” (Tesis, UNESA, 2017).

${ }^{3}$ Akramunnisa, "Ability Analysis Based on Math Problem Completing the Early Math Skills and Cognitive Style on Class VIII SMPN 13 Makassar," Jurnal Daya Matematis 5, no. 1 (March 17, 2017): 14-26, https://doi.org/10.26858/jds.v5i1.3028.

4 Baiduri Baiduri, "Gaya Kognitif Dan Hasil Belajar Matematika Siswa Field Dependence-Independence," AKSIOMA : Jurnal Matematika Dan Pendidikan Matematika 6, no. 1/Maret (2015), https://doi.org/10.26877/aks.v6i1/Maret.863. 


\section{Profil Kemampuan Mahasiswa Tadris Matematika...}

mereka seringkali harus menempuh cara berbeda untuk bisa memahami sebuah informasi atau pelajaran yang sama.

Perbedaan antar pribadi menyangkut sikap, pilihan atau strategi secara stabil yang menentukan cara - cara khas seseorang dalam menerima, mengingat, berpikir, dan memecahkan masalah disebut dengan "cognitive styles" atau gaya kognitif yang terdiri dari Field Independen (FI) dan Field Dependen (FD) 5 .

Dalam sumber yang sama dinyatakan bahwa Individu yang belajar dengan gaya field-independent cenderung menyatakan suatu gambaran lepas dari latar belakang gambaran tersebut, serta mampu membedakan objekobjek dari konteks sekitarnya dengan lebih mudah, memandang keadaan sekeliling lebih secara analitis dan umumnya mampu dengan mudah menghadapi tugas-tugas yang memerlukan perbedaan-perbedaan dan analisis. Umumnya mahasiswa yang field-independent kurang dipengaruhi oleh lingkungan, atau bahkan tidak dipengaruhi lingkungan. Adapun gaya belajar field-dependent kebalikan dari gaya belajar field-independent. Individu dengan gaya belajar ini menerima sesuatu secara global dan mengalami kesulitan dalam memisahkan diri dari keadaan sekitar, cenderung mengenal dirinya sebagai bagian dari suatu kelompok. Dalam interaksi sosial mereka cenderung untuk lebih perspektif dan peka. Umumnya mahasiswa dengan gaya belajar seperti ini sangat dipengaruhi oleh lingkungan atau bergantung pada lingkungan.

Gaya belajar berkaitan erat dengan pribadi seseorang, yang tentunya dipengaruhi oleh pendidikan dan riwayat perkembangannya. Gaya kognitif juga ditentukan oleh lingkungan yang dirancang dosen, karena itu dosen perlu memperhatikan gaya kognitif yang dimiliki oleh seorang mahasiswa dengan cara menerapkan berbagai macam strategi, pendekatan, model dalam perkuliahan yang mampu mengakomodir kedua jenis gaya kognitif tersebut.

Keanekaragaman model pembelajaran yang dapat dipilih oleh dosen untuk menyampaikan bahan ajar merupakan upaya bagaimana memilih

${ }^{5}$ Slameto, Belajar Dan Faktor Yang Mempengaruhinya (Jakarta: Rineka Cipta, 1995).

Al-Khwarizmi - 33 
berbagai alternatif strategi pembelajaran matematika yang hendak diterapkan, yang selaras dengan tingkat perkembangan kognitif, afektif, dan psikomotorik mahasiswa semester III.

Mengingat keterbatasan penulis, maka dalam penelitian ini dipilih faktor internal berupa kemampuan prasyarat dan gaya kognitif. Dengan asumsi kedua faktor internal tersebut berpengaruh terhadap kemampuan pemecahan masalah Program linier.

Tujuan penelitian ini adalah mendeskripsikan kemampuan mahasiswa yang berkemampuan prasyarat tinggi dengan gaya kognitif fiel dependen dalam menyelesaikan masalah, mendeskripsikan kemampuan mahasiswa yang berkemampuan prasyarat sedang dengan gaya kognitif fiel dependen dalam menyelesaikan masalah dan mendeskripsikan kemampuan mahasiswa yang berkemampuan prasyarat rendah dengan gaya kognitif fiel dependen dalam menyelesaikan masalah.

Manfaat yang diharapkan dengan adanya perlakuan yang dilakukan dalam penelitian ini dapat meningkatkan kemampuan mahasiswa dalam memecahkan masalah program linier, sehingga kemampuan kognitifnya dapat meningkat pula, memberikan informasi kepada dosen lain bahwa diharapkan mampu menerapkan berbagai pendekatan, metode, teknik dalam perkuliahan yang mampu mengakomodir gaya kognitif yang dimiliki mahasiswa. Sehingga terjadi peningkatan mutu pembelajaran matematika, dan penelitian ini diharapkan mampu memberikan informasi dan masukan untuk meningkatkan kualitas pembelajaran, kualitas dosen, dan pada akhirnya kualitas institute.

Bell memberikan definisi masalah sebagai: "a situation is a problem for a person if he or she aware of its existence, recognize that it requires action, wants of needs to act and does so, ad is not immediately able to resolve the problem". Suatu situasi dikatakan masalah bagi seseorang jika ia menyadari keberadaan situasi tersebut, mengakui bahwa situasi tersebut memerlukan tindakan dan tidak dengan segera dapat menemukan pemecahannya ${ }^{6}$. 1978).

${ }^{6}$ Frederick H. Bell, Teaching and Learning Mathematics (Dubuque, Ia: W. C. Brown Co, 


\section{Profil Kemampuan Mahasiswa Tadris Matematika...}

Pertanyaan akan merupakan masalah jika seseorang tidak mempunyai aturan/hukum tertentu yang segera dapat dipergunakan untuk menemukan jawaban pertanyaan tersebut ${ }^{7}$.

Masalah yang dimaksud dalam penelitian ini adalah suatu situasi tertentu dapat merupakan masalah bagi orang tertentu, tetapi belum tentu merupakan masalah bagi orang lain. Dengan kata lain, suatu situasi mungkin merupakan masalah pada waktu tertentu, akan tetapi belum tentu merupakan masalah baginya pada saat yang berbeda.

\section{Metode}

Jenis penelitian ini merupakan penelitian kualitatif yamg bertujuan untuk mendeskripsikan profil kemampuan mahasiswa Tadris Matematika semester III tahun 2017 dalam memecahkan masalah Program linier, ditinjau dari perbedaan tingkat kemampuan prasyarat dan gaya kognitif. Adapun lokasi penelitian bertempat di kampus IAIN Palopo.

Subjek penelitian ini adalah mahasiswa Tadris Matematika semester III tahun 2017 dengan pemilihan kelas C didasarkan pada pertimbangan: (1) Mendukung tujuan perkuliahan Program Linier antara lain: mengembangkan aktivitas kreatif yang melibatkan imajinasi, intuisi, dengan mengembangkan pemikiran divergen, orisinil, rasa ingin tahu, membuat prediksi, dugaan, serta mengembangkan kemampuan pemecahan masalah. (2) Mahasiswa kelas C lebih mudah untuk diwawancarai.

Skor untuk tes kemampuan prasyarat yang diperoleh diurutkan. Dari urutan nilai tersebut, peneliti kemudian dapat menentukan siswa-siswa yang termasuk dalam kategori tinggi $(75<\mathrm{x} \leq 100)$, kategori sedang (55<x $\leq$ 75) serta kategori rendah $(0 \leq x \leq 55)$. Sedangkan untuk skor tes GEFT digunakan untuk mengelompokkan subjek ke dalam FI dan FD. Skor dengan gaya kognitif $(10 \leq \mathrm{x} \leq 18)$ disebut memiliki gaya kognitif FI, Skor dengan gaya kognitif $(0 \leq \mathrm{x} \leq 9)$ disebut memiliki gaya kognitif FD.

Penetapan subjek penelitian dilakukan berdasarkan hasil tes kemampuan prasyarat dan gaya kognitif. Subjek utama penelitian ditetapkan

${ }^{7}$ Herman Hudoyo, Mengajar Belajar Matematika (LPTK Jakarta: Depdikbud, 1990).

Al-Khwarizmi - 35 
6 orang siswa, dengan 2 orang yang mewakili masing-masing kategori yang ada. Namun pada saat berada di lapangan, diperoleh perincian kelompok siswa dengan kemampuan prasyarat tinggi diwakili oleh 2 orang siswa dengan gaya kognitif field dependen, kelompok siswa dengan kemampuan prasyarat sedang diwakili oleh 2 orang siswa dengan gaya kognitif field dependen, kelompok siswa dengan kemampuan prasyarat rendah diwakili oleh 2 orang siswa dengan gaya kognitif field dependen.

Dari perincian subjek utama di atas hanya berjumlah 5 orang, karena dari 66 calon subjek, hanya diperoleh 1 orang siswa dengan kemampuan prasyarat tnggi dengan gaya kognitif field dependent(FD).

Instrumen yang digunakan adalah (1) Group Embedded Figures Test (GEFT) adalah tes yang diadaptasi dari hasil pengembangan Witkin at.al. (1977). Tes ini digunakan untuk mengetahui gaya kognitif seseorang secara psikologis yaitu: gaya kognitif field-independent dan field-dependent. Materi dari tes GEFT ini adalah berupa bangun-bangun geometri. Tes ini terdiri dari tiga bagian yaitu: bagian pertama terdiri dari 7 item soal, bagian kedua terdiri dari 9 item soal, dan bagian ketiga terdiri dari 9 item soal. Bagian pertama dari tes ini disiapkan untuk latihan peserta tes, sedangkan bagian kedua dan ketiga merupakan inti dari tes ini. (2) Tes kemampuan prasyarat dan tes kemampuan pemecahan masalah Program Linier, Pada tes kemampuan prasyarat, masalah yang diberikan pada mahasiswa berupa materi aljabar linier yaitu penyelesaian masalah Sistem persamaan linier dengan metode eliminasi Gauss. Pertanyaan yang diberikan mengarah pada kemampuan mahasiswa dalam memecahkan masalah mengikuti langkahlangkah penyelesaian masalah dari berbagai ahli. Mahasiswa diminta untuk menyelesaikan masalah sesuai dengan pertanyaan. Sedangkan tes kemampuan pemecahan masalah matematika merupakan kumpulan masalah-masalah matematika yang disusun dari materi program linier. Materi tes diformulasi dalam bentuk kalimat verbal (soal cerita). Tes kemampuan prasyarat dan tes kemampuan pemecahan masalah dikembangkan sendiri oleh peneliti. (3) Pedoman Wawancara, pada penelitian ini dilakukan dengan menggunakan wawancara tidak terstruktur. 


\section{Profil Kemampuan Mahasiswa Tadris Matematika...}

Pertanyaannya tidak harus sama untuk setiap subjek. Wawancara ini dilakukan untuk mengungkap secara kualitatif kemampuan mahasiswa dalam pemecahan masalah. Teknik wawancara adalah mahasiswa diberikan masalah Program linier untuk diselesaiakani gauss, dan mahasiswa diberikan waktu untuk memahaminya. Setelah mahasiswa dapat memahami masalah yang diberikan, maka selanjutnya mereka diwawancarai, apa yang dipikirkan, bagaimana cara ia menyelesaikannya. Data yang diperoleh adalah tulisan dan kata-kata mahasiswa.

Adapun Teknik Analisis Data yang digunakan adalah (1) Reduksi data adalah kegiatan yang mengacu kepada proses menyeleksi, memfokuskan, mengabstraksikan, dan mentransformasikan data mentah yang tertulis pada catatan lapangan. Apabila terdapat data yang tidak valid, maka data itu dikumpulkan tersendiri dan mungkin dapat digunakan sebagai verifikasi ataupun hasil-hasil samping lainnya. Validasi data sudah mulai dilakukan pada saat pengumpulan data berlangsung, yaitu dengan cara verifikasi. (2) Pada penelitian ini verifikasi data yang digunakan adalah triangulasi metode. Triangulasi metode dilakukan dengan memeriksa data dari seorang subjek dengan metode yang berbeda, yaitu tes tertulis dan wawancara ${ }^{8}$.

Pemaparan data yang meliputi pengklasifikasian dan identifikasi data, yaitu menuliskan kumpulan data yang terorganisir dan terkategori sehingga memungkinkan untuk menarik kesimpulan dari data tesebut. (3) Menarik kesimpulan penelitian dari data yang sudah dikumpulkan.

\section{Hasil Deskripsi Mahasiswa dengan Kemampuan Prasyarat Tinggi Gaya Kognitif Field Dependent}

Berikut ini adalah hasil deskripsi mahasiswa dengan kemampuan prasyarat tinggi gaya kognitif field dependent. Subjek $\mathrm{R}_{1}$ merupakan satunya responden yang berada pada kategori kemampuan prasyarat tinggi dengan gaya kognitif field dependent.

Subjek $\mathrm{R}_{1}$ mengetahui ada beberapa metode lain yang dapat ditempuh seperti metode grafik dan simpleks. Meskipun $\mathrm{R}_{1}$ telah mencoba untuk

${ }^{8}$ Sugiyono, Memahami Penelitian Kualitatif(Bandung: Alfabeta, 2007).

Al-Khwarizmi - 37 
mengerjakannya dengan kedua metode ini, Ia tidak dapat mengerjakannya dengan baik, karena mengalami masalah dengan angka yang besar lalu tidak melanjutkan pekerjaannya, dengan alasan bahwa subjek $\mathrm{R}_{1}$ tidak mampu mengingat langkah-langkahnya secara lengkap karena soalnya agak rumit, sehigga terkadang membuatnya tertunduk malu.

Untuk menguji keabsahan data hasil yang diperoleh pada wawancara dan hasil pekerjaan subjek. Hasil pengerjaan soal subjek $\mathrm{R}_{1}$ dibandingkan dengan wawancara. Pada hasil pengerjaan soal terlihat bahwa jawaban yang dikemukakan lengkap dan benar berdasarkan langkah-langkah pemecahan masalah menurut polya (memahami masalah, merencanakan penyelesaian, melaksanakan penyelesaian, dan melihat kembali).

Dalam memahami masalah, Subjek $\mathrm{R}_{1}$ mampu menuliskan apa yang diketahui, mampu menuliskan model matematika dengan menggunakan variabel $X_{1}$ dan $X_{2}$. Pada proses wawancara, Subjek $\mathrm{R}_{1}$ mampu menjelaskan dengan tegas mengapa model tersebut di tuliskan dalam merencanakan penyelesaian, subjek $\mathrm{R}_{1}$ mengumpulkan beberapa informasi yang berkaitan dengan persyaratan yang telah ditentukan, dan dipaparkan beberapa langkah yang dapat ditempuh untuk memecahkan masalah yang meliputi metode grafik dan metode simpleks. Subjek $\mathrm{R}_{1}$ mampu menyelesaikan masalah sesuai rencana, dengan meyakini bahwa langkah-langkah yang ditempuh sudah tepat, berdasarkan aturan-aturan yang telah ada. Pada tahap memeriksa kembali hasil yang diperoleh. Dari pemaparan di atas, diketahui bahwa hasil pekerjaan subjek $\mathrm{R}_{1}$ dalam memecahkan masalah sejalan dengan catatan wawancara. Setiap langkah yang dituliskan mampu dijelaskan dengan baik.

Jadi dapat disimpulkan bahwa mahasiswa dengan kemampuan prasyarat tinggi gaya kognitif field dependen mampu memahami permasalahan dan mampu mengungkapkan konsep yang diketahui dengan tepat. Ia dapat melaksanakan apa yang direncanakannya dengan baik dan benar walaupun tidak menampilkan seluruh rencana yang ada dipikirannya. Subjek $\mathrm{R}_{1}$ dapat menyelesaikan masalah Program linier dengan metode grafik dan simpleks. Subjek $\mathrm{R}_{1}$ dapat menunjukkan cara memeriksa kebenaran jawabannya dengan benar pula. Serta dalam memecahkan 


\section{Profil Kemampuan Mahasiswa Tadris Matematika...}

masalah Program linier, subjek $\mathrm{R}_{1}$ mengikuti langkah-langkah pemecahan masalah Polya yaitu memahami masalah, merencanakan pemecahan, melaksanakan penyelesaian sesuai rencana dan memeriksa kembali hasil yang diperoleh.

\section{Hasil Deskripsi Mahasiswa dengan Kemampuan Prasyarat Sedang Gaya Kognitif Field Dependent}

Berikut ini adalah hasil deskripsi mahasiswa dengan kemampuan prasyarat sedang gaya kognitif field dependent. Subjek dengan kemampuan ini adalah $\mathrm{R}_{3}$ dan $\mathrm{R}_{4}$.

Pertama adalah Subjek $\mathrm{R}_{3}$, memisalkan harga buku tulis adalah $X_{1}$, pensil adalah $X_{2}$. Subjek $\mathrm{R}_{3}$ mampu membuat model matematika dari soal. Hal ini menyiratkan bahwa di dalam pikirannya ada proses merencanakan penyelesaian, yaitu mengumpulkan informasi yang berkaitan dengan persyaratan yang telah ditentukan meskipun tidak dijelaskan secara rinci.

Hasil pengerjaan soal oleh subjek $\mathrm{R}_{3}$ dibandingkan dengan wawancara. Pada hasil pengerjaan soal terlihat bahwa jawaban yang dikemukakan benar berdasarkan langkah-langkah pemecahan masalah menurut polya (memahami masalah, merencanakan penyelesaian, melaksanakan penyelesaian, dan melihat kembali).

Dalam memahami masalah, Subjek $\mathrm{R}_{3}$ mampu menuliskan apa yang diketahui, mampu menuliskan model matematikadengan menggunakan variabel $X_{1}$ dan $X_{2}$, sedangkand alam merencanakan penyelesaian, subjek $\mathrm{R}_{3}$ merencanakan beberapa metode yang dapat ditempuh untuk memecahkan masalah yang meliputi metode grafik dan metode simpleks. Subjek $\mathrm{R}_{3}$ mampu menyelesaikan masalah dengan metode grafik, dan meyakini bahwa langkah-langkah yang ditempuh sudah tepat, berdasarkan aturan-aturan yang telah ada. Pada tahap memeriksa kembali hasil yang diperoleh, Subjek $\mathrm{R}_{3}$ tidak dapat menunjukkan cara memeriksa kebenaran jawaban yang telah dituliskan, karena ia sendiri kurang yakin dengan jawaban tersebut. Pada proses wawancara, Subjek $\mathrm{R}_{3}$ tidak mampu menjelaskan beberapa proses yang dituliskannya. Dari proses ini diketahui bahwa subjek $\mathrm{R}_{3}$ kurang mampu 
menggambarkan kemampuan pemecahan masalah, dan beberapa kesalahan matematika. Pemaparan di atas, diketahui bahwa hasil pekerjaan subjek $\mathrm{R}_{3}$ dalam memecahkan masalah sejalan dengan catatan wawancara. Setiap langkah yang dituliskan mampu dijelaskan dengan baik.

Jadi dapat disimpulkan bahwa Subjek $\mathrm{R}_{3}$ dengan kemampuan prasyarat sedang gaya kognitif field dependen mampu memahami permasalahan dan mampu mengungkapkan konsep yang diketahui dengan tepat, Subjek $\mathrm{R}_{3}$ melaksanakan pemecahan masalah sesuai dengan apa yang direncanakannya dengan baik dan benar, walaupun kadang-kadang terlihat pada proses wawancara ia berpikir keras dan lebih banyak menunduk. beberapa bagian yang menyiratkan bahwa subjek $\mathrm{R}_{3}$ kurang lugas, dan kurang yakin dalam menjelaskan langkah-langkah penyelesaian yang ditempuh, Subjek $R_{3}$ dapat menyelesaikan masalah Program linear hanya dengan satu alternatif jawaban yaitu metode grafik. Untuk metode grafik, responden $\mathrm{R}_{3}$ hanya mampu menggambar sketsa sumbu $\mathrm{x}$ dan sumbu $\mathrm{y}$. Setelah itu ia tidak mampu lagi menyelesaikannya, dalam memecahkan masalah Program Linear, subjek $\mathrm{R}_{3}$ mengikuti langkah-langkah pemecahan masalah Polya yaitu memahami masalah,(menuliskan apa yang diketahui dan ditanyakan) merencanakan pemecahan, melaksanakan penyelesaian sesuai rencana dan memeriksa kembali hasil yang diperoleh.

Kedua adalah Subjek $\mathrm{R}_{4}$, peneliti berasumsi bahwa subjek $\mathrm{R}_{4}$ dapat memahami permasalahan pada soal dengan baik. Meskipun dalam proses wawancara, subjek $\mathrm{R}_{4}$ tidak yakin dalam menjawab pertanyaan peneliti. Subjek $\mathrm{R}_{4}$ sering menunduk dan malu-malu.

Hasil pengerjaan soal oleh subjek $\mathrm{R}_{4}$ dibandingkan dengan wawancara. Pada hasil pengerjaan soal terlihat bahwa jawaban yang dikemukakan lengkap dan benar berdasarkan langkah-langkah pemecahan masalah menurut polya (memahami masalah, merencanakan penyelesaian, melaksanakan penyelesaian, dan melihat kembali).

Dalam memahami masalah, Subjek $\mathrm{R}_{4}$ mampu menuliskan apa yang diketahui, mampu menuliskan model matematika dengan menggunakan variabel $X_{1}$ dan $X_{2}$. Namun pada proses wawancara, subjek $\mathrm{R}_{4}$ tidak mampu 


\section{Profil Kemampuan Mahasiswa Tadris Matematika...}

menjelaskan dengan tegas mengapa model tersebut di tuliskan. Subjek $\mathrm{R}_{4}$ hanya merencanakan metode grafik, ia tidak mampu menyelesaikan masalah sesuai rencana, dan kurang yakin bahwa langkah-langkah yang ditempuh sudah tepat, berdasarkan aturan-aturan yang telah ada. Dari pemaparan di atas, diketahui bahwa hasil pekerjaan subjek $\mathrm{R}_{4}$ dalam memecahkan masalah sejalan dengan catatan wawancara tidak semua langkah yang dituliskan mampu dijelaskan dengan baik.

Jadi dapat disimpulkan bahwa Subjek $\mathrm{R}_{4}$ dengan kemampuan prasyarat sedang gaya kognitif field dependen mampu memahami permasalahan yang paparkan pada kedua masalah yang diberikan, kurang dalam melaksanakan pemecahan masalah sesuai dengan apa yang direncanakan sebelumnya. Ia kurang yakin dalam menjelaskan langkah-langkah penyelesaian yang ditempuh, dapat menyelesaikan masalah Program linear hanya dengan satu cara yaitu metode grafik, memecahkan masalah program linear mengikuti langkah-langkah pemecahan masalah Polya yaitu memahami masalah, merencanakan pemecahan, melaksanakan penyelesaian sesuai rencana dan memeriksa kembali hasil yang diperoleh, meskipun tidak dituliskannya secara rinci.

Jadi secara umum dapat disimpulkan bahwa mahasiswa dengan kemampuan prasyarat tinggi gaya kognitif field dependen $\mathrm{R}_{3}$ dan $\mathrm{R}_{4}$ sebagai responden yang berada pada sel kemampuan prasyarat sedang dengan gaya kognitif field dependent kurang mampu memahami permasalahan, dapat melaksanakan pemecahan masalah sesuai dengan apa yang direncanakan, walaupun kadang-kadang ada beberapa proses yang dikerjakan keliru. Terlihat pada proses wawancara ia berpikir keras dan lebih banyak menunduk dan beberapa bagian yang menyiratkan bahwa mereka kurang lugas, dan kurang yakin dalam menjelaskan langkah-langkah penyelesaian yang ditempuh. Serta dalam memecahkan masalah, subjek $R_{3}$ dan $R_{4}$ mengikuti langkah-langkah pemecahan masalah Polya yaitu memahami masalah,(menuliskan apa yang diketahui dan ditanyakan) merencanakan pemecahan, melaksanakan penyelesaian sesuai rencana dan memeriksa kembali hasil yang diperoleh. 


\section{Hasil Deskripsi Mahasiswa dengan Kemampuan Prasyarat Rendah Gaya Kognitif Field Dependent}

Berikut ini adalah hasil deskripsi mahasiswa dengan kemampuan prasyarat rendah gaya kognitif field dependent. Subjek dengan kemampuan ini adalah $\mathrm{R}_{5} \mathrm{dan} \mathrm{R}_{6}$.

Pertama adalah Subjek $\mathrm{R}_{5}$, dari hasil wawancara dapat diketahui bahwa subjek $\mathrm{R}_{5}$ kurang mampu memahami permasalahan pada soal dengan baik. Subjek $\mathrm{R}_{5}$ memulai dengan proses membaca dan berpikir (read and think) yang meliputi kegiatan mengidentifikasi fakta, mengidentifikasi pertanyaan dan mencari apakah ada informasi yang diperlukan untuk menyelesaikan masalah. Meskipun subjek $R_{5}$ mengetahui beberapa metode yang bisa ditempuh untuk menyelesaikan masalah Program linear yaitu metode grafik dan simpleks. Namun, Ia lupa langkah-langkahnya. Menurut Subjek $\mathrm{R}_{5}$, Ia mampu mengerjakan soal jika dalam bentuk umum, tapi susah jika dalam bentuk soal cerita.

Jadi dapat disimpulkan bahwa Subjek $R_{5}$ dengan kemampuan prasyarat sedang gaya kognitif field dependen kurang mampu memahami permasalahan yang paparkan pada kedua masalah yang diberikan, mulai melaksanakan pemecahan masalah Program linear dengan membaca dan berpikir (read and think), merencanakan penyelesaian yang akan ditempuh (eksplore and plan), memilih metode trial and error (coba-coba) untuk mencari jawaban (find and answer) atas masalah yang diberikan, memecahkan masalah cenderung mengikuti langkah-langkah pemecahan masalah menurut Krulik dan Rudnik yaitu read and think, explore and plan, select a strategy, Find and answer, reflect and extend. Cara ini pada dasarnya mengacu pada pemecahan masalah menurut Polya.

Kedua adalah Subjek $\mathrm{R}_{6}$, hasil wawancara diketahui bahwa subjek $\mathrm{R}_{6}$ dapat memahami permasalahan pada soal dan memecahkan masalah, Subjek $\mathrm{R}_{6}$ memulai dengan proses membaca dan berpikir (read and think) yang meliputi proses mengidentifikasi fakta, mengidentifikasi pertanyaan, mengidentifikasi informasi yang dibutuhkan untuk menyelesaikan masalah, membuat rencana penyelesaian. 


\section{Profil Kemampuan Mahasiswa Tadris Matematika...}

Subjek $\mathrm{R}_{6}$ mampu memecahan masalah dengan cara mencoba-coba. walaupun dengan metode trial and error (coba-coba) Namun, mampu menyebutkan beberapa metode yang dapat dilakukan untuk memecahkan masalah Program linear yaitu metode grafik dan metode simpleks. Serta subjek $\mathrm{R}_{6}$ mampu menjelaskan apa yang ada dipikirannya pada saat memecahkan masalah meskipun kurang yakin.

Dengan proses coba-coba tersebut, Subjek $\mathrm{R}_{6}$ mampu memecahkan masalah. Meskipun jawaban yang dikemukakan tidak menggambarkan ideide matematik. Dengan melihat penjelasan di atas, dapat dikatakan bahwa terjadi kesesuaian antara hasil pekerjaan dan hasil wawancara, yang menjelaskan bahwa subjek $\mathrm{R}_{6}$ mengalami kesulitan dalam pemecahan masalah.

Jadi dapat disimpulkan bahwa Subjek $\mathrm{R}_{6}$ dengan kemampuan prasyarat sedang gaya kognitif field dependen kurang mampu memahami permasalahan yang paparkan pada kedua masalah yang diberikan, mulai melaksanakan pemecahan masalah Program Linear dengan membaca dan berpikir (read and think), merencanakan penyelesaian yang akan ditempuh (eksplore and plan), memilih metode trial and error (coba-coba) untuk mencari jawaban (find and answer) atas masalah yang diberikan. Namun ia tidak yakin dalam membahasakan/membuktikan kebenaran hasil tersebut, dalam memecahkan masalah subjek $\mathrm{R}_{6}$ mengikuti langkah-langkah pemecahan masalah menurut Krulik dan Rudnik yaitu read and think, explore and plan, select a strategy, Find an answer, reflect and extend. Cara ini pada dasarnya mengacu pada pemecahan masalah menurut Polya.

Jadi secara umum dapat disimpulkan bahwa mahasiswa dengan kemampuan prasyarat tinggi gaya kognitif field dependen sebagai responden yang berada pada sel kemampuan prasyarat rendah dengan gaya kognitif field dependent kurang mampu memahami permasalahan yang paparkan pada kedua masalah yang diberikan. Subjek $\mathrm{R}_{5}$ dan $\mathrm{R}_{6}$ tidak mampu melaksanakan pemecahan masalah dengan benar, dan tidak yakin dalam menjelaskan langkah-langkah penyelesaian yang ditempuh dan dalam memecahkan masalah Program Linier, subjek $\mathrm{R}_{6}$ tidak mengikuti langkah- 
langkah pemecahan masalah menurut Krulik dan Rudnik yaitu read and think, explore and plan, select a strategy, Find an answer, reflect and extend.

\section{Simpulan}

\section{Penutup}

Adapun kesimpulan yang dianggap penting untuk disajikan adalah sebagaimana uraian berikut ini.

1. Profil subjek penelitian yang memiliki kemampuan prasyarat tinggi gaya kognitif field dependen, dalam hal proses pemecahan masalah menunjukkan kemampuan yang baik. Dalam arti dapat memahami masalah dengan tepat, dapat melaksanakan apa yang direncanakannya dengan baik dan benar, subjek juga dapat menyelesaikan masalah Program linier dengan metode grafik dan simpleks, dan dapat menunjukkan cara memeriksa kebenaran jawabannya dengan benar pula. Dalam memecahkan masalah, subjek mengikuti langkah-langkah pemecahan masalah Polya.

2. Profil subjek penelitian yang memiliki kemampuan prasyarat sedang gaya kognitif field dependent, dalam hal proses pemecahan masalah menunjukkan kemampuan yang cukup baik. Dalam arti dapat memahami masalah dengan tepat, masih kurang yakin saat melaksanakan pemecahan, namun sesuai dengan rencana. subjek juga dapat menyelesaikan masalah Program linier dengan metode grafik dan simpleks, dan dapat menunjukkan cara memeriksa kebenaran jawabannya dengan benar pula. Pada proses pemecahan masalah, Subjek kurang yakin mengikuti langkah-langkah pemecahan masalah Polya.

3. Profil subjek penelitian yang memiliki kemampuan prasyarat rendah gaya kognitif field dependent, tidak mampu melaksanakan pemecahan masalah dengan benar, dan tidak yakin dalam menjelaskan langkah-langkah penyelesaian yang ditempuh. Dalam memecahkan masalah Program linier, subjek tidak mengikuti langkah-langkah pemecahan masalah menurut Krulik dan Rudnik yaitu read and think, explore and plan, select a strategy, Find an answer, reflect and extend.. 
Saran

Mengacu kepada deskripsi pembahasan hasil penelitian dan kesimpulan di atas maka dapat disarankan kepada:

1. Dosen diharapkan mampu mengakomodir gaya kognitif yang dimiliki mahasiswa, sehingga dapat menggunakan metode pembelajaran tepat.

2. Pihak institusi diharapkan memberikan perhatian khusus kepada mahasiswa terkait dengan penggolongan mahasiswa ke dalam salah satu tipe gaya kognitif Fiel Dependen. Dengan harapan para dosen yang mengajar mampu mengakomodir karakteristik tersebut.

\section{Daftar Pustaka}

Akramunnisa. "Ability Analysis Based on Math Problem Completing the Early Math Skills and Cognitive Style on Class VIII SMPN 13 Makassar." Jurnal Daya Matematis 5, no. 1 (March 17, 2017): 14-26. https://doi.org/10.26858/jds.v5i1.3028.

Baharullah. "Kesulitan Siswa kelas I SMU YP. PGRI 3 Makassar Dalam Menyelesaikan Soal Terapan Sistem Persamaan Linear Dua Variabel.” Tesis, UNESA, 2017.

Baiduri, Baiduri. "Gaya Kognitif Dan Hasil Belajar Matematika Siswa Field Dependence-Independence." AKSIOMA: Jurnal Matematika Dan Pendidikan Matematika 6, no. 1/Maret (2015). https://doi.org/10.26877/aks.v6i1/Maret.863.

Bell, Frederick H. Teaching and Learning Mathematics. Dubuque, Ia: W. C. Brown Co, 1978.

Hudoyo, Herman. Mengajar Belajar Matematika. LPTK Jakarta: Depdikbud, 1990.

Slameto. Belajar Dan Faktor Yang Mempengaruhinya. Jakarta: Rineka Cipta, 1995.

Sugiyono. Memahami Penelitian Kualitatif. Bandung: Alfabeta, 2007.

Suherman, Erman. Strategi Pembelajaran Matematika Kontemporer. Bandung: Universitas Pendidikan Indonesia, 2001. 
Halaman ini sengaja dikosongkan

Al-Khwarizmi - 46 